\title{
Beech coppice conversion to high forest: results from a 31-year experiment in Eastern Pre-Alps
}

\author{
Barbara Mariotti ${ }^{1}$. Giorgio Alberti ${ }^{2,3}$ (D) Alberto Maltoni $^{1} \cdot$ Andrea Tani $^{1}$ • \\ Pietro Piussi ${ }^{1}$
}

Received: 8 February 2017 / Accepted: 28 April 2017 /Published online: 17 May 2017

(C) INRA and Springer-Verlag France 2017

\begin{abstract}
- Key message Selective thinning is a more viable method for beech coppice conversion to high forest when compared with thinning from below as it enhances tree growth, reduces mortality of the remaining trees, and allows to obtain stands with a higher mechanical stability and larger crowns.

- Context Beech forests in North-East Italy have been largely managed as coppice. Due to socio-economic changes, a large
\end{abstract}

\section{Handling Editor: Aaron R. Weiskittel}

Contribution of the co-authors

Pietro Piussi designed the experiment and coordinated the data collection; Barbara Mariotti, Giorgio Alberti, and Alberto Maltoni analyzed the data; Giorgio Alberti, Barbara Mariotti, Alberto Maltoni, and Pietro Piussi wrote the paper; and Andrea Tani supervised the work and contributed to the discussion of the results.

Giorgio Alberti

giorgio.alberti@uniud.it

Barbara Mariotti

barbara.mariotti@unifi.it

Alberto Maltoni

alberto.maltoni@unifi.it

Andrea Tani

andrea.tani@unifi.it

Pietro Piussi

pietro.piussi@gmail.com

1 Dipartimento di Gestione Sistemi Agrari, Alimentari e Forestali, Università di Firenze, Florence, Italy

2 Dipartimento di Scienze Agroalimentari, Ambientali ed Animali, Università di Udine, Udine, Italy

3 CNR-IBIMET, Florence, Italy conversion to high forests program started in the second half of the past century.

- Aims A long-term experiment testing the effects on tree growth and stability of two different conversion methods (thinning from below - method A; selective thinning - method B) was implemented.

- Methods Both silvicultural treatments started in 1979 with a first thinning followed by a second one in 1997. All trees were periodically measured in order to assess mortality, stability, and growth during the period 1979-2010. In 2010, an assessment of stem quality and crown size was also performed.

- Results Both methods were economically viable, but method B acted with a higher intensity both in 1979 and in 1997, thus making the harvest more profitable for the owners. Moreover, method B enhanced tree growth, especially in the period after the first thinning, reduced mortality, and allowed to obtain stands with a higher mechanical stability and with larger crowns.

- Conclusion It would be possible to adopt some of the criteria prescribed with method $\mathrm{B}$ in future thinnings over the large areas actually managed with method $\mathrm{A}$, as prescribed by the law.

Keywords Coppice conversion · Beech · Thinning $\cdot$ Fagus sylvatica

\section{Introduction}

Throughout history, coppicing has been the basis for silvopastoral systems with temporary cropping, husbandry, hunting, gathering, and beehives (Emanuelsson 2009). However, a recent reconstruction of European forest management from 1600 to 2010 suggests that coppice management in 2010 was at its lowest in over 400 years (McGrath et al. 2015). In 
fact, coppices have been starting to lose their economic importance since the second half of the nineteenth century because of the substitution of fuelwood with gas and kerosene, even though such a trend was temporary interrupted during the two World Wars and the interbellum.

At present, independent estimates suggest that $15 \%$ of the European forest (i.e., about 23 million ha) is currently under coppice management (McGrath et al. 2015). In Italy, coppices now represent $42 \%$ of the forest area (Gasparini and Tabacchi 2011), while they accounted for 56\% in 1936 (Ferretti et al. 2016). Moreover, these coppices are nowadays fragmented in many age classes, and the number of coppices managed according to customary rotation periods is extremely limited (11\% according to Gasparini and Tabacchi 2011).

Beech (Fagus sylvatica L.) forests characterize the landscape of many mountain areas in Europe, and although they have been often managed as high forest (Hahn and Fanta 2001), relatively large areas have been also managed as coppice for the production of firewood and charcoal, especially at lower elevation and in southern European countries. According to the Italian National Forest Inventory, beech forests cover approximately $1,035,103$ ha $(9.9 \%$ of the country's forest area), $61 \%$ of which are publicly owned, mostly by municipalities (Gasparini and Tabacchi 2011). In the past, managing beech for the production of timber was not particularly common in Italy, with few exceptions such as the Cansiglio Forest (North-East Italy), where a shelterwood system with a rotation period of 140 years and a regeneration period of 20 years have been applied. On the contrary, the use of beech wood as fuelwood or charcoal was quite common in several rural areas in Alps and Pre-Alps (Del Favero 2004). Thus, most of the beech coppice forests were managed through clear cutting with standards (60-80 standards ha $^{-1}$; rotation period of 16-24 years; Del Favero 2004; Del Favero et al. 1998; Hofmann 1963 ) or through selection cuts as uneven aged coppices (selection coppice; Piussi and Alberti 2015; Coppini and Hermanin 2007; Nocentini 2009). Following rural depopulation and the already mentioned changes in the socioeconomic conditions that occurred in the last century, many of these stands have been abandoned or have been progressively thinned to prepare them to the final conversion to high forest (Andriollo et al. 1987; Ciancio et al. 2006; Nocentini 2009). Moreover, policymakers started to support coppice conversion to high forests with the idea that these lasts were more efficient for protection against natural hazards, for biodiversity conservation, for the development of recreational and tourist activities, and for the protection of water resources (Hasenauer 2006). A similar situation has also been observed for beech and other coppices in many European countries (Canellas et al. 2004; Van Calster et al. 2007).
Generally, Italian beech coppices at the end of their traditional rotation period $(t)$ are characterized by high stem density (more than 4000 shoots ha ${ }^{-1}$; Piussi and Alberti 2015). In order to prepare the stand for the final conversion cut, local forestry regulation foresaw a first thinning from below when the coppice was 35-50 years old, leaving 800-1500 stem ha ${ }^{-1}$, sometime accompanied by the removal of co-dominant shoots with the consequent release of a limited number of shoots on each stool (mixed thinning) (Amorini and Gambi 1977). Thinning from below was often preferred to other methods by local regulations, as it is easy to be implemented by forest workers (i.e., only removal of suppressed trees) and to be controlled by the forest service. Thereafter, further thinnings from below or mixed are applied every 10 20 years. When tree density reaches $150-250$ stems ha $^{-1}$ able to produce enough seeds, the felling (i.e., shelterwood system) can take place (Piussi and Alberti 2015). On the whole, the conversion of beech coppices to high forest is a quite long process (120-150 years; Nocentini 2009) and data on the response to the final regeneration cut are not yet available in the literature (Cutini et al. 2015).

Alternatively to thinning from below, the selective thinning (Leibundgut 1978; Schaedelin 1942) can be adopted with the aim to further increase the share of large diameter trees and yield value and to further improve timber quality and stand stability. In such a case, the selection of the crop trees is made with respect to stem quality, crown characteristics, vitality, stability, and the spatial distribution of trees and not only on their social position within the stand. The classical selective thinning is characterized by repeating the selection of the crop trees (Leibundgut 1978; Schaedelin 1942), whose number strongly decreases with time since the first thinning.

The issue of moving from low-mixed thinnings to selective thinning in aged beech coppices has been recently tackled by Becagli et al. (2016). The authors suggested that the change from the more conservative tending to the selective thinning may promote growth at the crown level and a more balanced crown to stem ratio.

The setup of experimental trials comparing different conversion techniques and/or thinning intensities is crucial in the development of operational guidelines for an economically sustainable harvest, with reduced potential negative impacts on biodiversity and the environment (Mattioli et al. 2015). Moreover, the choice of an appropriate thinning type, frequency, and intensity is an important decision for coppice conversion to high forest in order to combine the benefits of harvesting for forest owners with all the other ecosystem services.

In 1979, a large experiment was started in Cansiglio Forest (Andriollo et al. 1987) to gather information about 
the effectiveness of the two thinning types described above in order to provide useful management guidelines to convert the beech coppices of that area. The first thinning was applied in 1979, and a second one was performed 18 years later. From 1979 to 2010, data were collected periodically in 20 plots, but, unfortunately, fortuitous disturbances through time forced to abandon several of these experimental plots. Nevertheless, more than 30 years of continuous observations are now available in the remaining plots. Such long-term studies on beech coppice conversion, including data on yield and stand growth and biomass, are not commonly available in literature.

In this framework, the present research was aimed to test if selective thinnings, such as those generally applied to beech high forests in the young stages (Boncina et al. 2007) are more convenient to prepare old beech coppice to the final conversion cuts in terms of stand growth, stem and crown quality, and an economic return in comparison to the traditional thinning from below.

\section{Material and methods}

The study area is located along the southern-facing slope of Cansiglio Plateau at a mean altitude of $1030 \mathrm{~m}$ a.s.l. in the Western Friuli Venezia Giulia, Italy $\left(45^{\circ} 58^{\prime} 00^{\prime \prime} \mathrm{N}\right.$; $\left.12^{\circ} 27^{\prime} 00^{\prime \prime} \mathrm{E}\right)$. The mean annual temperature is around $7^{\circ} \mathrm{C}$, and the annual precipitation is $1820 \mathrm{~mm}$. The area is characterized by calcareous bedrock and widespread karst phenomena; thus, in addition to the absence of any surface hydrography, a large number of cavities, furrowed fields (Karrenfelds), sinkholes (dolina), and caves are present. Over undulating surfaces or along the ridges, soils are moderately deep, with a high differentiated profile and a clay accumulation (Luvisols), while on the sides of the karst depressions and on the steeper slopes, soils are shallower and can be classified as Cambisols and Leptosols. The forests cover 1830 ha and are characterized by pure beech stands (42\%) at the upper elevations and by hophornbeam (Ostrya carpinifolia Scop.) and manna ash (Fraxinus ornus L.) mixed stands (36\%) at the southern face slope and lower elevations. Some coniferous plantations, mainly spruce (Picea abies Karst), are present on former pastures (5\%) and, down in the plain, durmast (Quercus petraea Liebl.) and chestnut (Castanea sativa Miller) mixed stands are also present (14\%). Almost half of the beech forests ( $370 \mathrm{ha}$ ) is traditionally managed as high forest through the application of a shelterwood system with a rotation period of 140 years, while the other half (399 ha) is represented by old coppices in conversion to high forests.

As said before, a large experiment aimed to test the two different thinnings (see below) in beech coppice conversions started in 1979 (Andriollo et al. 1987), but fortuitous disturbances through time forced to abandon several experimental plots, so that now only three paired plots have a complete 30 year dataset (Tables 1 and 2). Due to the karst morphology of the area, plot size was adjusted in order to consider similar conditions and to avoid sinkholes. The last utilization as coppice took place in the early sixties of the last century. When the research started in 1979, the dominant stand heights were between 12 and $14 \mathrm{~m}$. All forests were owned by local Municipalities, which decided to start the conversions in order to foster change towards a regime of multifunctional high forests.

The study compared two different conversion methods: (i) thinnings from below (method A) prescribing to leave 1300 2000 shoots ha ${ }^{-1}$, with at least three dominant shoots stool ${ }^{-1}$, without interruption of tree cover. This was the traditional method adopted in the area and thus used as control in our experiment. (ii) Selective thinning (method B) aimed to select the best shoots ( 1 or 2 ) on each stool and to isolate the crowns in order to enhance their growth. When only dominated shoots were present on a stool, they were left if they were not interfering with forest operations or the growth of the dominant stems. At that time, this approach was considered innovative within the context of beech forest conversions.

A first thinning was performed in 1979 and a second in 1997 (Table 3). Diameter at breast height (dbh) of all trees in the plots and a subsample of heights to build hypsometric curves were recorded in 1979 (before and after thinning), 1986, 1992, 1997 (before and after thinning), 2002, and 2010. Total number of trees per hectare and basal area $\left(\mathrm{m}^{2} \mathrm{ha}^{-1}\right)$ were calculated for each plot. Total volume for each plot $\left(\mathrm{m}^{3} \mathrm{ha}^{-1}\right)$ was calculated at each survey date from dbh using always the same volume table (Andriollo et al. 1987). Total annual increment between survey dates $\left(\mathrm{I} ; \mathrm{m}^{3} \mathrm{ha}^{-1}\right.$ year ${ }^{-1}$ ) was
Table 1 Mean characteristics of the three selected coppices in 1979 before treatments application (Andriollo et al. 1987)

\begin{tabular}{llcccc}
\hline Coppice & $N\left(N \mathrm{ha}^{-1}\right)$ & $G\left(\mathrm{~m}^{2} \mathrm{ha}^{-1}\right)$ & $V\left(\mathrm{~m}^{3} \mathrm{ha}^{-1}\right)$ & $d_{\text {avg }}(\mathrm{cm})$ & $H_{\text {avg }}(\mathrm{m})$ \\
\hline Lama di Co & 3256 & 4.03 & 158.3 & 9.7 & 13.0 \\
Pian della Chitarra & 2815 & 24.48 & 159.3 & 10.5 & 13.4 \\
Costa Lusiera & 2021 & 19.93 & 123.3 & 11.2 & 13.6 \\
\hline
\end{tabular}

$N$ number of stems per hectare, $G$ basal area, $V$ standing volume, $d_{\text {avg }}$ mean diameter, $H_{\text {avg }}$ mean height 
Table 2 Main plot characteristics

\begin{tabular}{clllllc}
\hline Treatment & Plot & Coppice & Plot area $\left(\mathrm{m}^{2}\right)$ & Aspect & Slope (\%) & Altitude (m a.s.1.) \\
\hline \multirow{2}{*}{ A } & A & Lama di Co & 1880 & W & 35 & 1100 \\
& E & Pian della Chitarra & 2360 & SE & $28-35$ & 910 \\
& N & Costa Lusiera & 1916 & S-SW & 30 & 1075 \\
B & B & Lama di Co & 3725 & W & 36 & 1070 \\
& D & Pian della Chitarra & 3900 & SE & 25 & 950 \\
& M & Costa Lusiera & 2395 & S-SW & 30 & 1070 \\
\hline
\end{tabular}

calculated using the Gurnaud's control method (La Marca 1999):

$I=\frac{V_{2}-V_{1}+V_{h}}{t_{2}-t_{1}}$

where $V_{1}$ and $V_{2}$ are the volumes at survey times 1 and 2, respectively, and $V_{\mathrm{h}}$ is the harvested wood during the period $t_{2}-t_{1}$. The corresponding growth rate $\left(\mathrm{Gr} ; \%\right.$ year $\left.^{-1}\right)$ was calculated according to the equation:

$\mathrm{Gr}=\frac{I}{V_{1}}$

During the last survey (2010), a circular subplot in each plot containing at least 15 dominant trees was set up in order to investigate stem and crown characteristics. Maximum $\left(D_{\max 1.30}\right)$ and minimum $\mathrm{dbh}\left(D_{\min 1.30}\right)$ at $1.30 \mathrm{~m}$ were measured to calculate stem eccentricity $\left(D_{\max 1.30}: D_{\min 1.30}\right)$, mean basal diameter $\left(D_{0 \mathrm{~m}}\right)$ and mean diameter at $3 \mathrm{~m}$ height $\left(D_{3 \mathrm{~m}}\right)$ were measured to compute stem taper $\left(D_{3 \mathrm{~m}}: D_{0 \mathrm{~m}}\right)$, minimum $\left(R_{\min }\right)$ and maximum $\left(R_{\max }\right)$ crown radius were measured to compute crown area and asymmetry (La Marca 1999). Tree height $\left(H_{\mathrm{tot}}\right)$ and crown insertion height $\left(H_{\text {crown }}\right)$ were used to assess the relative crown insertion height $\left(H_{\text {crown }}: H_{\text {tot }}\right)$, while $\mathrm{H}_{\text {tot }}$ and $\mathrm{dbh}$ were used to calculate stem stability index ( $\mathrm{dbh}: H_{\text {tot }}$ ).

The effect of thinning methods on all stand dendrometric and structural parameters were analyzed using the nonparametric Mann-Whitney $U$ test as, due to the limited

Table 3 Thinning intensities in 1979 and 1997 in terms of number of individuals $(N)$, harvested basal area $(G)$ and harvested volume $(V)$

\begin{tabular}{cccc}
\hline Treatment & $\Delta N(\%)$ & $\Delta G(\%)$ & $\Delta V(\%)$ \\
\hline \multicolumn{2}{l}{ First thinning (1979) } & & \\
A & $49.6 \pm 4.4$ & $31.9 \pm 5.1$ & $35.2 \pm 4.2$ \\
B & $60.4 \pm 3.8$ & $44.0 \pm 2.4^{*}$ & $44.3 \pm 2.3$ \\
Second thinning (1997) & & \\
A & $48.9 \pm 0.4$ & $26.2 \pm 0.5$ & $23.9 \pm 0.3$ \\
B & $55.7 \pm 1.8^{*}$ & $36.4 \pm 2.5^{*}$ & $33.6 \pm 2.4^{*}$ \\
\hline
\end{tabular}

Mean \pm st. err. $(n=3)$

$A$ thinning from below, B selective thinning $* p<0.05$ number of replicates per treatment, it does not require any assumption about the form of the data distributions. Statistical analysis were performed using Stata10 (@StataCorp LP, USA), and all data are reported as mean \pm standard error along all the text, in tables and figures $(n=3)$.

\section{Results}

The first thinning (1979) reduced stem density by $49.6 \pm 4.4 \%$ and $60.4 \pm 3.8 \%$ in method A and method B, respectively ( $p=0.13$; Fig. 1; Table 3). Similarly, basal area was significantly reduced by $31.9 \pm 5.1 \%$ and $44.0 \pm 2.4 \%(p<0.05)$. In 1997 , 18 years after the thinnings begun, mortality had considerably reduced the number of stems in the plots thinned from below (method A): on the whole, about $23.7 \pm 5.8 \%$ of the shoots died, especially in the smallest dbh classes, possibly because of insufficient light, while mortality in method B plots reduced stand

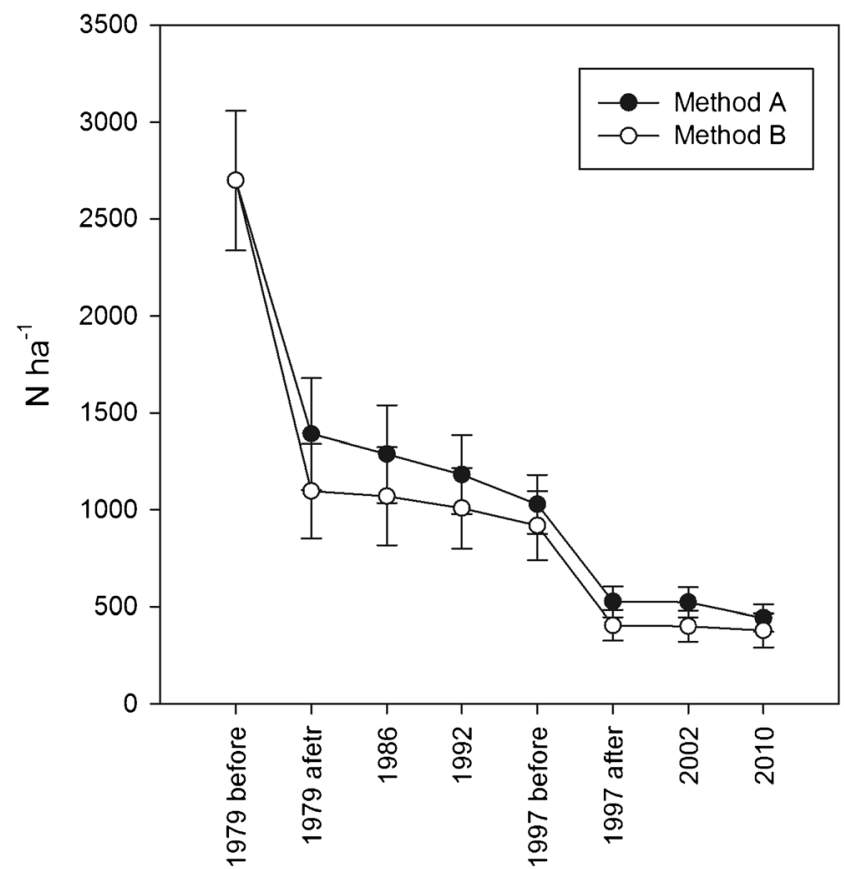

Fig. 1 Mean stand density $\left(N \mathrm{ha}^{-1}\right)$ with time for thinning from below (method A, solid symbols) and selective thinning (method B, open symbols). Vertical bars indicate standard error $(n=3)$ 
Table 4 Stand volume before the first thinning $\left(V_{1979}\right)$, final volume $(H)$, total annual increment $(I)$, and annual growth rate $(\mathrm{Gr})$ volume $\left(V_{2010}\right)$, total harvested

\begin{tabular}{cllccr}
\hline Treatment & $V_{1979}\left(\mathrm{~m}^{3} \mathrm{ha}^{-1}\right)$ & $V_{2010}\left(\mathrm{~m}^{3} \mathrm{ha}^{-1}\right)$ & $H\left(\mathrm{~m}^{3} \mathrm{ha}^{-1}\right)$ & $I\left(\mathrm{~m}^{3} \mathrm{ha}^{-1}\right.$ year $\left.^{-1}\right)$ & $\mathrm{Gr}(\%)$ \\
\hline A & $147.0 \pm 11.8$ & $188.3 \pm 3.9$ & $95.3 \pm 6.1$ & $4.4 \pm 0.2$ & $3.1 \pm 0.4$ \\
B & $147.0 \pm 11.8$ & $167.0 \pm 25.3$ & $126.9 \pm 9.3 *$ & $4.7 \pm 0.6$ & $3.3 \pm 0.6$ \\
\hline
\end{tabular}

Mean \pm st. err. $(n=3)$

$A$ thinning from below, treatment $B$ selective thinning $* p<0.05$

density of $15.1 \pm 2.6 \%$. Moreover, the diameter distribution shifted with time since the first thinning from an inverse Jshaped curve to a normal one in both treatments. Method A mostly removed trees in the lower diameter classes, while method B concentrated on higher classes (data not shown).

The second thinning (1997) following method B criteria significantly reduced both the stem density and the basal area $(p<0.05)$. Mortality was again higher in method A than in B in the following 13 years $(16.3 \pm 1.0 \%$ and $7.9 \pm 5.9 \%$, respectively). Thus, at the end of the experimental period (2010), stem density was not significantly different in the two treatments (442 \pm 70 and $379 \pm 87$ stem ha $^{-1}$, respectively; $p=0.51$ ).

Resprouting after thinnings took place in most of the stools, but new shoots growth has been poor and heights rarely exceeded $1 \mathrm{~m}$ (data not shown). Thus, consequences on the main stand growth should have been negligible.

As far as volume is concerned, a total of $95 \pm 6$ and $127 \pm 9 \mathrm{~m}^{3} \mathrm{ha}^{-1}$ were harvested in A and B, respectively $(p<0.05$; Table 4$)$ and the final standing volume in 2010 was slightly, even though not significantly, lower in method B plots than in A (167 vs. $188 \mathrm{~m}^{3} \mathrm{ha}^{-1}$; Table 4). However, if the harvested wood is also considered, the picture is reversed (294 vs. $284 \mathrm{~m}^{3}$ ha ${ }^{-1}$; Fig. 2).

The first thinning following method B prescriptions had a positive, even though not significant, effect on the growth rate and on the annual increment (18\%). However, the overall effect of the two selective thinnings (1979 and 1997) was slightly positive (7\%; Table 4) in comparison to the two thinnings from below (method $\mathrm{A})$.

The higher reduction in stand density also changed resource allocation and enhanced crown enlargement of the released stems (Table 5). In fact, method B generally enhanced all indexes related to crown quality (Table 5), even though not always significantly. In particular, crown area and its relative height were increased by 38 and $6 \%$, respectively, while crown asymmetry was reduced by $7 \%$. Moreover, method B significantly increased stem taper in the first $3 \mathrm{~m}(p<0.05$; Table 5), while stem eccentricity did not change $\left(D_{\max 1.30}: D_{\min 1.30}=1.06\right.$, on average $)$. In particular, when trees with dbh lower than $35 \mathrm{~cm}$ are considered, the average stem taper was $1.52 \pm 0.21$ and $1.74 \pm 0.09 \mathrm{~cm} \mathrm{~m}^{-1}$ in methods $\mathrm{A}$ and $\mathrm{B}$, respectively. These values increased when trees with dbh higher than $35 \mathrm{~cm}$ are considered $(2.20 \pm 0.10$ and $2.39 \pm 0.14 \mathrm{~cm} \mathrm{~m}^{-1}$ ).

The selective thinning reduced $(-18 \%)$ the $H_{\mathrm{t}}: D_{1.30}$ ratio, thus increasing stand mechanical stability and no damages caused by wind or snow have been noticed in the lower part of the stem during the observation period in both treatments.

\section{Discussion}

The basal area harvested through the thinning from below was slightly higher than reported in a similar study investigating
Fig. 2 Total volume (solid line) and current standing volume (dashed line) with time for thinning from below (A) and selective thinning (B). Vertical bars indicate standard error $(n=3)$
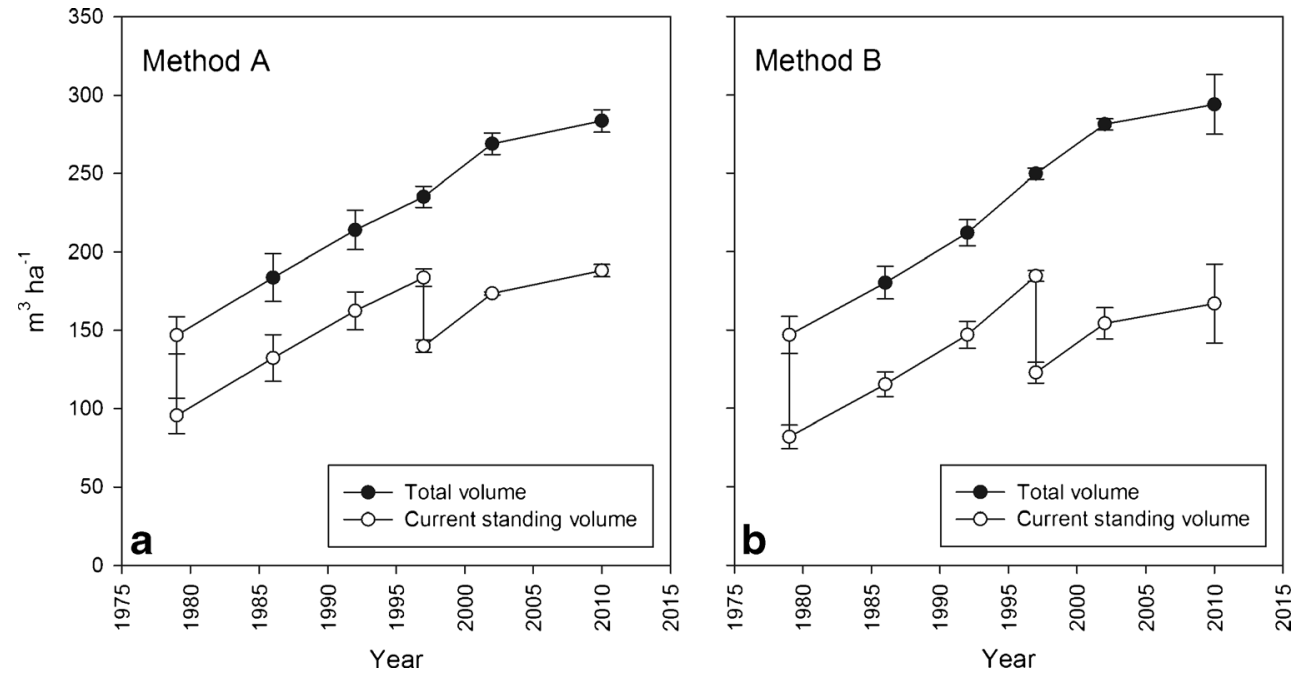
Table 5 Mean stem and crown quality for the dominant trees in 2010

\begin{tabular}{clllllll}
\hline Treatment & Stem & & Crown & & & $\begin{array}{l}\text { Stability } \\
\text { index }\end{array}$ \\
\cline { 2 - 3 } & $\begin{array}{l}\text { Eccentricity } \\
\left(D_{\max 1.30}: D_{\min 1.30}\right)\end{array}$ & $\begin{array}{l}\text { Taper } \\
\left(D_{3 \mathrm{~m}}: D_{0 \mathrm{~m}}\right)\end{array}$ & & Asymmetry & $\begin{array}{l}\text { Relative } \\
\text { height }\end{array}$ & $\begin{array}{l}\text { Crown } \\
\text { area }\left(\mathrm{m}^{2}\right)\end{array}$ & $\begin{array}{l}H_{\mathrm{t}}: D_{1.30} \\
\end{array}$ \\
\hline $\mathrm{A}$ & $1.05 \pm 0.01$ & $0.86 \pm 0.01$ & $0.83 \pm 0.01$ & $0.49 \pm 0.05$ & $48.4 \pm 3.3$ & $68 \pm 7$ \\
$\mathrm{~B}$ & $1.06 \pm 0.01$ & $0.83 \pm 0.01^{*}$ & $0.77 \pm 0.04$ & $0.52 \pm 0.09$ & $63.8 \pm 5.5$ & $56 \pm 5$ \\
\hline
\end{tabular}

Mean \pm st. err. $(n=3)$

$D_{\text {max } 1.30}$ maximum diameter at $1.30 \mathrm{~m}, D_{\min 1.30}$ minimum diameter at $1.30 \mathrm{~m}, D_{0 m}$ mean basal diameter, $D_{3 m}$ mean diameter at $3 \mathrm{~m}, H_{t}$ total tree height, $D_{1.30}$ mean diameter at $1.30 \mathrm{~m}$

$* p<0.05$ the coppice conversion to high forest in Italy (Ciancio et al. 2006). In terms of harvested volume, both thinnings removed the average amount of wood which can be generally harvested in Alpine beech coppices with a rotation period of 20 years and average current annual increment of $8.1 \mathrm{~m}^{3} \mathrm{ha}^{-1}$ years $^{-1}$ (Del Favero et al. 1998; Gasparini and Tabacchi 2011). Thus, active conversion through medium-heavy thinnings made silvicultural intervention profitable due to the shortly repeated harvesting and intermediate volumes (Amorini et al. 2010). In fact, both the methods were economically viable, even though almost all harvested material was suitable as fuelwood only. On the other hand, as the harvested wood was significantly higher in method B plots, the selective thinnings was more profitable for the forest owner. Mechanization of harvesting operations, changes in stand structure taking place through time, and persistent request of fuelwood by a peculiar market such as pizzerias suggest that thinnings before final conversion cuts will be still economically feasible also in the next future. Moreover, the selective thinning reduced the mortality of the remaining trees in the years following the harvest. Our data on mortality in the plots thinned from below are close to those reported by Piovesan et al. (1995) who found, in a naturally developing 34 -year-old beech coppice, nearly 900 live stools per ha with a reduction of about $20 \%$ of the original value over a period of 10 years of observation. On the contrary, Amorini and Fabbio (1995) reported higher values for a 47 years old beech coppice (824 live stools per ha with a reduction of about $30 \%$ of the original value after 20 years). In both the treatments, the resprout of the stools was irrelevant. This is an important issue since a dominated layer made of new sprouts can hinder the growth of the future regeneration after the final cut (Ciancio et al. 2006; Cutini et al. 2015).

The selective thinning had an overall positive effect on the growth rate and annual increment, even if stronger in 1979 than in 1997. This phenomenon, known as "growth acceleration," has been reported also in other Central European forests (Boncina et al. 2007). These results are also in accordance with Pretzsch model, which forecasts an increase in periodic volume increment with decreasing stand density in young beech stands on fertile sites (Pretzsch 2005).
Similarly to Mattioli et al. (2015), the higher reduction in stand density following selective thinning changed resource allocation and enhanced crown enlargement and an increase in the overall stability of the released stems. Such an improvement in crown quality indexes is related to a reduction in competition as well as to an improvement in the radiation environment in the lower part of the tree crown and to a prompt response of beech crowns (Canellas et al. 2004). The selective thinning reduced slenderness $\left(H_{\mathrm{t}}: D_{1.30}\right.$ ratio), but increased stem taper (Table 5). Even though trees with a high degree of taper are generally considered of poor form, the European Standard EN1316-1 "Hardwood round timber Qualitative classification - Part 1: Oak and beech" is not considering taper in its classification and thus it is difficult to say whether the measured stem taper increase is acceptable in terms of timber quality.

\section{Conclusions}

Both thinning approaches to start the conversion of old coppices into high forest stands were suitable both from an ecological and economic point of view. With thinning from below (method A), less attention is paid in choosing trees to be cut, but the impact on productivity is smaller. On the contrary, the selective thinning (method B) has shown an advantage as far as productivity is concerned, in reducing mortality, and in the long run, stems grown from stools could possibly provide better timber (size, shape) than those grown under method A, but further research on wood characteristics is needed. On the other side, method B can be implemented only by skilled workers to avoid additional costs due to marking trees before felling.

Presumably, very few beech coppices will be available in the future for replicating the conversion process we described, since most of them have been already included in the conversion program, whereas over large areas - managed until now with method A, as prescribed by law - it would be possible to adopt some of the criteria prescribed with method B in future thinnings (future crop tree selection, higher thinning intensity, leaving dominated trees) to further ameliorate the structure of 
the stands and prepare for the final cuts (i.e., group shelterwood system, irregular shelterwood system).

Acknowledgements As the long list of colleagues and collaborators in the Regional Forest Service in Aviano and Pordenone during 30 years would require one whole page, we thank them collectively. We also thank Barbara Vinceti and Rosè Andriollo.

\section{References}

Amorini E, Fabbio G (1995) Ricerche sull'“invecchiamento dei cedui”: riflessioni sul trattamento di conversione. Ital For e Mont 46:193204

Amorini E, Fabbio G, Bertini G (2010) Dinamica del ceduo oltre turno e avviamento ad alto fusto dei cedui di faggio. Risultati del protocollo Germano Gambi sull'Alpe di Catenaia (Arezzo). Ann Cent Ric Selvic 36:151-172

Amorini E, Gambi G (1977) Il metodo dell'invecchiamento nella conversione dei cedui di faggio. Ann Ist Sper Selvic 8:23-42

Andriollo R, Azzalini A, Ceschel A, Gogliani P, Piussi P, Stiavelli S (1987) Tagli di avviamento all'altofusto in cedui di faggio del Friuli occidentale. Ann. Accad. Ital. di Sci. For. 36

Becagli C, Bertini G, Di Salvatore U, Fabbio G, Fabrizio F, Salvati L (2016) Monitoring managed forest structure at the compartmentlevel under different silvicultural heritages: an exploratory data analysis in Italy. J Sustain For 35:234-250. doi:10.1080/10549811. 2016.1154472

Boncina A, Kadunc A, Robic D (2007) Effects of selective thinning on growth and development of beech ( Fagus sylvatica L.) forest stands in south-eastern Slovenia. Ann For Sci 64:47-57. doi:10.1051/ forest:2006087

Canellas I, Del Rio M, Roig S, Montero G (2004) Growth response to thinning in Quercus pyrenaica Willd coppice stands in Spanish central mountain. Ann For Sci:61

Ciancio O, Corona P, Lamonaca A, Portoghesi L, Travaglini D (2006) Conversion of clearcut beech coppices into high forests with continuous cover: a case study in central Italy. For Ecol Manag 224:235 240. doi:10.1016/j.foreco.2005.12.045

Coppini M, Hermanin L (2007) Restoration of selective beech coppices: a case study in the Apennines (Italy). For Ecol Manag 249:18-27. doi: 10.1016/j.foreco.2007.04.035

Cutini A, Chianucci F, Giannini T, Manetti MC, Salvati L (2015) Is anticipated seed cutting an effective option to accelerate transition to high forest in European beech (Fagus sylvatica L.) coppice stands? Ann For Sci 72:631-640. doi:10.1007/s13595-015-0476-7

Del Favero R (2004) I boschi delle regioni alpine italiane. CLEUP, Padova

Del Favero R, Bortoli P, Dreossi G, Lasen C, Vanone G (1998) La vegetazione forestale e la selvicoltura nella regione Friuli Venezia
Giulia. Regione Autonoma Friuli Venezia Giulia. Direzione Regionale delle Foreste, Servizio Selvicoltura

Emanuelsson U (2009) The rural landscapes of Europe. Formas, Stockholm

Ferretti, F., Sboarina, C., Tattoni, C., Vitti, A., Zatelli, P., Geri, F., Pompei, E., Ciolli, M., 2016. The 1936 Italian Kingdom Forest Map reviewed: a dataset for landscape and ecological research.

Gasparini, P., Tabacchi, G., 2011. L'Inventario Nazionale delle Foreste e dei serbatoi forestali di Carbonio INFC 2005. Secondo inventario forestale nazionale italiano. Metodi e risultati. Ministero delle Politiche Agricole, Alimentari e Forestali; Corpo Forestale dello Stato. Consiglio per la Ricerca e la Sperimentazione in Agricoltura, Unità di ricerca per il Monitoraggio e la Pianificazione Forestale. Edagricole-Il Sole 24 ore, Bologna

Hahn, K., Fanta, J., 2001. Contemporary beech forest management in Europe. Working Report 1.

Hasenauer H (2006) Sustainable forest management. Growth models for Europe. Springer Berlin, Heidelberg

Hofmann A (1963) La converesione dei cedui di faggio. Ann Accad Ital di Sci For 12:145-164

La Marca O (1999) Elementi di dendrometria. Patron Editore, Bologna

Leibundgut, H., 1978. Die Waldpflege. P. Haupt.

Mattioli W, Ferrari B, Giuliarelli D, Mancini L, Portoghesi L, Corona P (2015) Conversion of mountain beech coppices into high forest: an example for ecological intensification. Environ Manag. doi:10. 1007/s00267-015-0549-2

McGrath MJ, Luyssaert S, Meyfroidt P, Kaplan JO, Bürgi M, Chen Y, Erb K, Gimmi U, McInerney D, Naudts K, Otto J, Pasztor F, Ryder J, Schelhaas M-J, Valade A (2015) Reconstructing European forest management from 1600 to 2010. Biogeosciences 12:4291-4316. doi:10.5194/bg-12-4291-2015

Nocentini S (2009) Structure and management of beech ( Fagus sylvatica L.) forests in Italy. iForest - Biogeosciences For 2:105-113. doi:10. 3832/ifor0499-002

Piovesan G, Hermanin L, Schirone B (1995) Considerazioni sulla crescita e lo sviluppo di un ceduo matricinato di faggio (Fagus sylvatica L.) di età avanzata. Ital For e Mont 50:404-424

Piussi P, Alberti G (2015) Selvicoltura generale: boschi, società e tecniche colturali. Compagnia delle Foreste, Arezzo

Pretzsch H (2005) Stand density and growth of Norway spruce (Picea abies (L.) karst.) and European beech (Fagus sylvatica L.): evidence from long-term experimental plots. Eur J For Res 124:193-205. doi: 10.1007/s10342-005-0068-4

Schaedelin, W., 1942. Die Durchforstung als Auslese- und Veredelungsbetrieb hoechster Wertleistung. Bern-Leipzig.

Van Calster H, Baeten L, De Schrijver A, De Keersmaeker L, Rogister JE, Verheyen K, Hermy M (2007) Management driven changes (1967-2005) in soil acidity and the understorey plant community following conversion of a coppice-with-standards forest. For Ecol Manag 241:258-271. doi:10.1016/j.foreco.2007.01.007 